\title{
What Is the Meaning of Educational Injustice? A Case for Reconceptualizing a Heterogeneous Concept
}

\author{
A. C. Nikolaidis \\ The Obio State University
}

Educational injustice is a topic of concern for educators in all capacities. Educational researchers in universities and research institutes aim to disrupt patterns of educational injustice by increasing access to quality education. Educational policymakers, whether in favor of market principles or public options, aim to tackle educational injustice by breaking barriers to quality education for disadvantaged populations. School administrators and faculty aim to mitigate the effects of educational injustice by creating more equitable and inclusive school environments. These efforts notwithstanding, it is unclear what different educators are trying to accomplish in the name of disrupting educational injustice, the reason being that, like educational justice, educational injustice is a heterogeneous concept and encompasses a multiplicity of injustice categories. The ambiguity that this heterogeneity generates is especially problematic since proposed solutions may succeed or fail depending on one's criteria of evaluation. For instance, restricting the limitless pursuit of education by privileged individuals may be a sound solution from a distributive perspective but not necessarily so from an epistemic one. ${ }^{1}$ Such discrepancies may manifest in educational research, policymaking, and practice depending on one's explicit or implicit philosophical assumptions. This suggests a lack clarity in the use of the term educational injustice and consistency in endeavors to disrupt educational wrongs. ${ }^{2}$

This essay provides such clarity and advances a case for reconceptualizing educational injustice in educational research, policymaking, and practice to better coordinate remedial efforts and identify pressing educational problems. ${ }^{3}$ The structure is as follows: Section I outlines different categories of educational injustice to establish the concept's heterogeneity. Section II addresses problems with this heterogeneity and the related difficulty of conceptualizing educational injustice in all-encompassing terms. It further 
suggests that limiting the scope of educational injustice is best accomplished through the use of educational criteria. Section III argues for a narrow conceptualization of educational injustice along two essential educational axes: knowledge and formation. Section IV expounds the contours of a twopronged account of educational injustice built on the aforementioned axes and presents the strengths of this account.

\section{CATEGORIES OF EDUCATIONAL INJUSTICE}

Before determining how to best conceptualize educational injustice, one must ask what is the meaning of educational injustice in the first place? This question might seem superfluous given that we all use the term intelligibly and know what promotes or inhibits justice without having to refer to precise definitions. However, the different categories that scholars use to conceptualize educational injustice can vary greatly and conflict with each other, rendering the meaning of educational injustice elusive. ${ }^{4}$ Outlining some of these categories can help clarify:

Distributive injustice refers to unfair distribution of school funding and other educationally relevant resources or opportunities. ${ }^{5}$ Under this category, educational injustice manifests in unequal educational systems where schools that serve the socioeconomically advantaged are well-endowed, have experienced teachers, and provide a wealth of educational resources to their students while those that serve the socioeconomically disadvantaged are ill-funded, have inexperienced teachers and high rates of teacher attrition, and struggle to provide even the minimal resources required by law.

Cultural injustice refers to cultural insensitivity in educational settings and lack of recognition of marginalized students' cultural heritage. ${ }^{6}$ Under this category, educational injustice manifests as lack of culturally relevant pedagogy or curricula in schools that serve marginalized students and that disregard student backgrounds and inculcate hegemonic values. ${ }^{7}$ For instance, while many students may be native Spanish speakers, all courses may be taught in English or no teachers may speak Spanish. While many students may be descendants of indigenous populations, all history lessons may cele- 
brate America's colonial legacy or disregard indigenous history.

Political injustice refers to lack of proper student representation and blatant disregard for students' educational interests and needs. ${ }^{8}$ Such injustice, according to progressive educators, manifests in most versions of traditional education which disregard the needs and contributions of students while sustaining an autocratic form of classroom management and knowledge transmission. ${ }^{9}$ Similar accounts of educational injustice have been advanced by critical pedagogues who view the inability of students to participate as equals in the educational process as dehumanizing and oppressive. ${ }^{10}$

Epistemic injustice refers to discriminatory treatment of students as knowers or to the withholding of epistemically relevant resources from students. ${ }^{11}$ Under this category, educational injustice manifests as disregard of students' contributions by their teachers because of students' perceived immaturity, as inability of marginalized students to understand the significance of their experiences due to biased epistemic resources, or as refusal to provide students with knowledge that they have a right to know-such as religious schools denying their students access to knowledge about contraception. ${ }^{12}$

Formative injustice refers to constraints on one's ability to regulate their self-formation or to the undue foreclosing of one's educational potential. This category of educational injustice may manifest as refusal to support one's children in developing a sense of autonomy, rendering one's children unable to regulate their capacities and resources and to pursue intentional ends that accord with their dispositions. Moreover, it may manifest as educational restrictions - such as forbidding certain forms of knowledge- that may interfere with a student's ability to flourish in ways that are unknown at an early age. ${ }^{13}$

Retributive injustice refers to failure to punish students for rule violations of moral or procedural significance. ${ }^{14}$ It also refers to unjust student punishment, understood as either punishment for insignificant violations or punishment that is unjustifiably severe. ${ }^{15}$ Educational injustice here may 
manifest as teacher abuse of discretionary disciplinary power or as arbitrary disciplinary decision-making. For instance, student-faculty cultural mismatch renders some students vulnerable to unjustified punishment for behaviors considered appropriate by their own cultural standards and to unjustifiable double standards in disciplinary severity. ${ }^{16}$

Restorative injustice refers to failure to restore school community relations that were disrupted by a rule violation. ${ }^{17}$ This may manifest as unrectified harm, inflicted on one student by another, that disrupts student learning. While punishing the wrongdoer may serve retributive justice, failure to redress the harm and mend student relationships may damage or distress the school community rendering students unable to take advantage of educational opportunities. Similar accounts of educational injustice may be advanced on the basis of the more expansive categories of community justice and transformative justice. ${ }^{18}$

Some of these categories are more popular, and more extensively theorized, than others. Distributive injustice, for instance, has arguably been the dominant framework for theorizing educational injustice in philosophy of education and educational policy. Debates abound regarding the patterns of distribution of educational goods and the particular educational content to be distributed. ${ }^{19}$ Furthermore, this list is not exhaustive. There are many other categories - both philosophical and non-philosophical—by which to conceptualize educational injustice. ${ }^{20}$

\section{CONCEPTUALIZING EDUCATIONAL INJUSTICE}

The diversity of categories presented in Section I renders it difficult to develop a consistent comprehensive account of educational injustice. Doing so would require conceptualizing it in too rudimentary a manner to be of analytic value; for instance, as unfair treatment that carries educational significance. Moreover, conceptualizing educational injustice in broad terms would likely create inconsistencies between different categories of educational injustice. For instance, disrupting distributive injustice might require that all students be taught an equally rigorous curriculum, cultural injustice a cultur- 
ally differentiated curriculum, and political or epistemic injustice a personally individualized curriculum. Similarly, disrupting retributive injustice might require that wrongdoings be remedied through appropriate punishment of rule violators, restorative injustice through non-punitive community-building practices, and formative injustice through educationally-valuable potentiality-enhancing practices. Such conflicts are not only possible but may also be difficult to resolve. For this reason, all-encompassing accounts of educational injustice are unhelpful. This compels us to conceptualize educational injustice in narrower terms that may privilege some categories over others, subsume some categories under others, or even preclude some categories altogether.

Given the need for a narrower account, one must ask which category or categories are most appropriate for conceptualizing educational injustice? In addressing this question, Winston Thompson has suggested that educational justice (or, for my purposes, injustice) is best theorized using categories from within the discipline of education, rather than categories that are imported from other disciplines and applied to education. ${ }^{21}$ Thompson's suggestion seems to be the best way of dealing with this problem for three reasons. First, a prima facie argument can be made for using educational categories to conceptualize educational injustice by virtue of their object of consideration. Since educational injustice is injustice that pertains to education, it makes sense that it be evaluated on distinctly educational grounds. The burden of proof then lies with those who prefer to conceptualize educational injustice in non-educational terms to show why it should be so conceptualized - why, that is, educational considerations should be secondary to non-educational ones (within educational settings, nonetheless). Second, educational injustice categories encompass non-educational injustice considerations (such as the unfair distribution of economic resources or the use of cruel punishment for rule violations). However, these considerations are relevant only to the extent that they fall under the purview of educational categories of injustice, rather than in themselves. Third, when conflicts arise, we have a clear criterion for prioritizing considerations. Within educational settings, disrupting educational categories of injustice must always take prior- 
ity over non-educational ones.

Going back to our list of categories (Section I), we see that of the seven only two fulfill Thompson's standard: epistemic and formative injustice. Epistemic injustice is concerned with knowledge-the content of education - and pertains to restrictions that inhibit us from transmitting and/or acquiring knowledge. ${ }^{22}$ Formative injustice is concerned with formation - the process and end goal of education — and pertains to the formative significance of our experiences and to restrictions that inhibit us from controlling our self-formation. ${ }^{23}$ Given their educational nature, both epistemic and formative injustice have been suggested as essential educational categories to be used as measures of educational injustice. ${ }^{24}$ On the other hand, the first three categories — distributive, cultural, and political injustice-come from the fields of economics, political theory, and moral philosophy and thus tend to be used as measures of social injustice. ${ }^{25}$ Similarly, the last two categories_retributive and restorative injustice_come from the fields of moral philosophy and criminology and tend to be used as measures of corrective or criminal injustice. When non-educational categories are used to conceptualize educational injustice, they are applied to educational settings and limited to educational considerations. Instead of addressing the distribution of social or primary goods, they address the distribution of educational goods; instead of addressing the political representation of citizens within social institutions, they address the political representation of students within educational institutions; instead of addressing the punishment of violators of laws, they address the punishment of violators of school rules; and so on.

KNOWLEDGE AND FORMATION AS ESSENTIAL EDUCATIONAL AXES

The categories of epistemic and formative injustice are each structured around an essential educational axis: knowledge and formation, respectively. ${ }^{26}$ Each captures a fundamental aspect of education and places it at the center of justice considerations. As such, they are prime candidates for a definitive account of educational injustice. 
Epistemic injustice is concerned with wrongs to one's capacity as a knower and with related harms to one's ability to acquire and/or transmit knowledge. ${ }^{27}$ Epistemic wrongs and harms are salient because they impede one's participation in intrinsically valuable educational practices-e.g., knowledge acquisition and knowledge contribution—and one's access to intrinsically valuable knowledge. ${ }^{28}$ This stands in opposition to non-educational categories which are concerned with the instrumental value of knowledge for non-educational purposes, such as socioeconomic advancement or social justice. ${ }^{29}$ Infringing on one's ability to acquire knowledge is an epistemic injustice even if the knowledge at issue holds no instrumental (non-educational) value. It is an epistemic injustice even if the knowledge to be acquired is questionable on non-educational grounds. Consider the use of propaganda or indoctrination to protect students from exposure to antisocial or oppressive ideas; while it may be right from a social or moral standpoint, it is wrong from an educational one on epistemic grounds.

Formative injustice is concerned with wrongs to one's formative capacities and with related harms to one's ability to regulate their self-formation. Formative wrongs and harms are salient because they impede one's engagement in intrinsically valuable formative practices-e.g., pursuit of one's potentialities and regulation of one's development in line with one's aims and dispositions. ${ }^{30}$ This stands in opposition to non-educational conceptions which view formative regulation as a means for accomplishing non-educational purposes, such as socioeconomic advancement or the development of civic-mindedness. ${ }^{31}$ Infringing on one's ability to develop their potentialities and create new possibilities for becoming who they might be interested (or have an interest) in becoming is a formative injustice even if it holds non-educational value. Consider the refusal of a particular community to allow students to develop critical thinking skills or provide them with opportunities to develop potentialities that do not align with community values or promote community aims. While this might be right from a social or cultural standpoint, it is wrong from an educational one on formative grounds.

Both epistemic and formative injustice capture something essential 
about education. One highlights the centrality of knowledge in the educational process while the other the centrality of formation. However, I contend that their use and theorizing as separate categories creates a false dichotomy that problematically makes them appear as independent from one another. Knowledge is not acquired for its own sake nor is the mind a repository for information that serves no purpose other than regurgitation upon demand. It has formative value and shapes one's understanding of the world around them, informs one's conduct, refines one's purpose, and generates opportunities for new occupations. Identifying education with knowledge acquisition alone reduces it to content memorization for the purpose of acing assessments. Similarly, self-formation is not something esoteric to be achieved in the abstract nor a form of introspection severed from real-world experience. To be formative, an experience must involve knowledge acquisition, produce understanding, and afford one insight that could not have been gained otherwise. Through interaction with one's environment, one learns something that (re)forms them in particular ways. In this sense, knowledge and formation are always intertwined. The false dichotomy between knowledge and formation disregards that what one knows determines who one is and aspires to become, their attitudes, habits, and modes of engaging with the world, but also that who one is determines the knowledge they are likely to seek out, the kind of knower they are, and their intellectual proclivities. Knowledge and formation, then, though they can be theorized as two analytically distinct aspects of education, in practice cannot be separated. As such, for an account of educational injustice to be both essentially educational and satisfactory it must incorporate both essential educational axes and their mutual interactions.

One might object to the designation of knowledge and formation as two essential educational axes, on grounds that such designation privileges the categories of epistemic and formative injustice at the expense of other categories of educational injustice. Relatedly, one might argue that a conception of educational injustice that is based on said categories prioritizes particular educational aims over others. ${ }^{32}$ While it is certainly true that 
epistemic and formative injustice are privileged over other categories, they need not preclude considerations that pertain to other categories. Rather, non-educational considerations are adjusted to meet educational standards. For instance, distributive wrongs are limited to the unfair distribution of knowledge rather than opportunities for professional success which, strictly speaking, are not controlled by systems of education but by employers and the job market. ${ }^{33}$ More importantly, while epistemic and formative injustice prioritize wrongs that pertain to knowledge acquisition and self-formation, they remain neutral with regard to knowledge content and educational aims to the extent that knowledge acquisition and self-formation are not unduly interfered with. For instance, a choice of schools to prioritize civic knowledge for the purpose of developing responsible citizens (a goal of social justice) need not be an epistemic or formative injustice as long as students are not being denied substantive access to other knowledge and their self-formation is not unduly restricted.

TOWARD A TWO-PRONGED ACCOUNT OF EDUCATIONAL

\section{INJUSTICE}

Based on the line of reasoning presented in Section III, I argue that the most satisfactory account of educational injustice would combine the two essential educational categories of epistemic and formative injustice. This combination allows for scholarship on each of these categories to be examined in relation to the other but also for new scholarship to be developed at the intersection of the two.

With regard to the relational approach, scholars must examine epistemic and formative injustice in light of each other. That is to say, they must examine the formative effects of epistemic injustice and the epistemic effects of formative injustice. Epistemic injustice as a category refers to two kinds of wrongs. The first are wrongs that are inflicted on someone in their capacity as a knower as a result of prejudice against their identity. These include the deflation of marginalized speakers' credibility by privileged listeners, the inability of marginalized individuals to understand the significance of their 
experiences because of biases in dominant forms of knowledge, and the inability of marginalized individuals to make knowledge contributions because those privileged refuse to acknowledge the validity of marginalized forms of knowledge. ${ }^{34}$ The second kind are wrongs that violate one's right to know what it is in one's interest to know as a result of being lied to or kept ignorant. ${ }^{35}$ Epistemic injustice has obvious formative consequences such as the inability to develop in ways that are in one's interest. One may be unable to make epistemic contributions, with formative implications for themself and others who depend on their contributions, or to become aware of socially-induced formative constraints and take action to eliminate them. Formative injustice refers to the wrong of distorting one's formative capacities. This includes undue interference with one's ability to determine their formative ends and regulate their formative capacities, and undue foreclosing of potentialities in ways that could impede one from becoming someone who it is in their interest to become or from endorsing ways of life that it is in their interest to endorse. ${ }^{36}$ Formative injustice has obvious epistemic consequences such as the inability to acquire or transmit knowledge that is in one's interest to acquire or transmit. One may be unable to pursue knowledge that they could have been, had they cultivated a particular potentiality.

With regard to the intersectional approach scholars must examine educational injustice as a hybrid category where epistemic injustice and formative injustice are theorized in unison. This hybrid category — which, using Christopher Martin's terminology, can be called formative epistemic injustice- is concerned with epistemic injustice and formative injustice, but only insofar as each of them contributes to or is a result of the other. ${ }^{37}$ Accordingly, formative epistemic injustice can be defined as "a wrong against someone in their capacity as a knower which occurs as a result of or results in malformation." 38 The wrong to one in their capacity as a knower refers to any or all of the wrongs of epistemic injustice and malformation to any or all of the wrongs of formative injustice, as described above. This intersectional approach is especially valuable because, by prioritizing the interconnection of knowledge and formation, it foregrounds the educational nature of the injustices that 
fall under its purview.

I will conclude by presenting three reasons why conceptualizing educational injustice as the hybrid category of formative epistemic injustice (relational and/or intersectional) is preferable to other accounts. First, it is broad enough to encompass educational wrongs of non-educational categories. For example, it encompasses wrongs of cultural injustice which is a form of epistemic oppression or rejection of marginalized epistemic contributions that leads to malformation of marginalized students in the form of internalized hegemonic norms. It also encompasses wrongs of political injustice such as the rejection of students' epistemic contributions and the structuring of classrooms as inegalitarian spaces governed by an autocratic epistemic authority. These wrongs distort student formation by transforming them into compliant citizens who unquestioningly adhere to the demands of perceived epistemic authorities.

Second, this hybrid category is comprehensive enough to subsume other important considerations, such as distributive or corrective ones, without facing the limitations of their parent categories. For example, instead of arguing whether particular patterns of educational resource distribution are unfair from the perspective of distributive injustice, we ensure that distributions do not contribute to formative epistemic injustice by infringing on self-formation and knowledge acquisition or transmission. This requirement demonstrates that the promotion of standard deliberative accounts of civic education unjustly impairs the development of students with intellectual disabilities into active citizens and perpetuates ableist norms. ${ }^{39}$ It also demonstrates that distributive equality is problematic insofar as it interferes with student formation by restricting knowledge acquisition. ${ }^{40}$ Similarly, instead of arguing whether retributive or restorative accounts better capture failure to address student wrongdoings, we ensure that disciplinary responses are not formatively and epistemically unjust. If a school rule is epistemically oppressive and malformative, schools ought to abandon it and students should not be held accountable for violating it. Moreover, disciplinary responses that foreclose formative opportunities and/or violate students' right to know- 
e.g., exclusionary punishment_-are educationally unjust and thus impermissible within educational settings.

Third, this hybrid category is expansive enough to account for educational injustices that fall outside the purview of formal education. For example, under formative epistemic injustice the spread of propaganda and ideology by media and other socializing agencies that aspire to control public opinion are considered manifestations of educational injustice, since exposure to propaganda and ideology distorts people's capacity as knowers and their ability to regulate their self-formation. ${ }^{41}$ The same applies to the use of behavior modification technologies by social media and other internet platforms to manipulate users and produce profit-yielding behaviors. ${ }^{42}$ The expansiveness of formative epistemic injustice highlights the need to extend the regulative scope of educational policy beyond formal educational institutions. It also highlights the need to reject epistemically oppressive and formatively debilitating educational practices that result in failure to protect students from miseducative socializing influences outside schools.

1 See Harry Brighouse and Adam Swift's justification for levelling down educational attainment on distributive grounds and Ben Kotzee's related critique of levelling down on epistemic grounds. Brighouse and Swift, "Equality, Priority, and Positional Goods," Ethics 116, no. 3 (2006): 471-497; Ben Kotzee, “Educational Justice, Epistemic Justice, and Levelling Down,” Educational Theory 63, no, 4 (2013): 331-349.

2 Winston Thompson has advanced a similar critique that is specifically targeted at educational research. Winston Thompson, "Rethinking Discussions of Justice in Educational Research: Formative Justice, Educational Liberalism, and Beyond," Teachers College Record 118, no. 10 (2016): 1-3.

3 The emphasis on injustice, as opposed to justice, foregrounds the preva- 
lence of educational wrongs in contemporary educational settings.

4 For an account on the diversity of justice in educational research see Kathy Hytten and Sylvia C. Bettez, "Understanding Education for Social Justice," Educational Foundations 25, no. 1-2 (2011): 7-24.

5 Harry Brighouse and Adam Swift, "Putting Educational Equality in its Place," Education Finance and Policy 3, no. 4 (2008): 444-466.

6 Axel Honneth, "Integrity and Disrespect: Principles of a Conception of Morality Based on the Theory of Recognition," Political Theory 20, no. 2 (1992), 187-201; Charles Taylor, “The Politics of Recognition,” in Multiculturalism: Examining the Politics of Recognition, ed. Amy Guttman (Princeton: Princeton University Press, 1994), 25-73.

7 Gloria Ladson-Billings, "Toward a Theory of Culturally Relevant Pedagogy," American Educational Research Journal 32, no. 3 (1995): 465-491.

8 Nancy Fraser, Scales of Justice: Reimagining Political Space in a Globalizing World (Cambridge, UK: Polity Press, 2008).

9 See, for instance, John Dewey, "Democracy in Education," in John Dewey: The Middle Works, vol. 3 of The Collected Works of John Dewey, 1882-1953, ed. Jo Ann Boydston (Carbondale: Southern Illinois University Press, 1977), 229-239.

10 Paulo Freire, Pedagogy of the Oppressed, trans. Myra Bergman Ramos (New York, NY: Continuum, 2011).

11 Kotzee, "Educational Justice, Epistemic Justice, and Levelling Down." 12 Karin Murris, “The Epistemic Challenge of Hearing Child's Voice,” Studies in Philosopby and Education 32, no. 3 (2013): 245-259; Miranda Fricker, Epistemic Injustice: Power and the Ethics of Knowing (New York, NY: Oxford University 
Press, 2007); David Coady, “Two Concepts of Epistemic Injustice,” Episteme 7, no. 2 (2010): 101-113.

13 Robert McClintock, "Formative Justice: The Regulative Principle of Education,” Teachers College Record 118, no. 10 (2016): 1-38; Thompson, "Rethinking Discussions of Justice in Educational Research," 1-16.

14 Michael Hand, "On the Necessity of School Punishment," Theory and Research in Education 18, no. 1 (2020): 10-22.

15 Consider how black students' behavior is often wrongfully perceived as disruptive or how black students are often punished more harshly. Cheryl Staats, Implicit Racial Bias and School Discipline Disparities: Exploring the Connection (Columbus, OH: Kirwan Institute, 2014); Kelly Welch and Allison Ann Payne, "Racial Threat and Punitive School Discipline," Social Problems 57, no. 1 (2010): 25-48.

16 Staats, Implicit Racial Bias and School Discipline Disparities: Exploring the Connection 7-9.

17 Bryan R. Warnick and Campbell F. Scribner, "Discipline, Punishment, and the Moral Community of Schools," Theory and Research in Education 18, no. 1 (2020): 98-116; Howard Zher, Changing Lenses: A New Focus for Crime and Justice (Scottdale, PA: Herald Press, 1990).

18 Adam Crawford and Todd Clear, "Community Justice: Transforming Communities through Restorative Justice?," in Restorative Community Justice: Repairing Harm and Transforming Communities, eds. Gordon Bazemore and Mara Schiff (Cincinnati, OH: Anderson Publishing, 2001), 127-149; Ruth Morris, Stories of Transformative Justice (Toronto, ON: Canadian Scholars' Press Inc., 2000). 
19 Debates address whether the distribution of educational goods ought to aim for equality, adequacy, or benefit of the least advantaged and whether or not to promote civic, patriotic, vocational, or other kinds of education.

20 Other examples include, on the philosophical side, compensatory injustice or failure to compensate for past educational wrongs (e.g., inadequate affirmative action programs in university admissions) and, on the non-philosophical side, racial injustice or unfair treatment on the basis of race (e.g., establishing curricular tracking programs that negatively and disproportionately impact students of color).

21 Thompson, "Rethinking Discussions of Justice in Educational Research," $1-3$.

22 Alvin I. Goldman, Knowledge in a Social World (New York: Oxford University Press, 1999), chapter 11.

23 Robbie McClintock, Formative Justice (New York: The Reflective Commons, 2019).

24 For epistemic justice as a measure of educational justice see Kotzee, “Educational Justice, Epistemic Justice, and Levelling Down.” For formative justice as a measure of educational justice see Thompson, "Rethinking Discussions of Justice in Educational Research."

25 See Fraser, Scales of Justice: Reimagining Political Space in a Globalizing World for an account of social justice that encompasses all three categories. 26 I am open to considering other essential educational injustice categories, though, to my knowledge, other such categories have not been advanced. 27 I use knowledge in broad terms and include theoretical or academic knowledge, practical knowledge (know-how), moral knowledge, and tacit or 
embodied knowledge.

28 Coady, "Two Concepts of Epistemic Injustice"; Fricker, Epistemic Injustice; Kotzee, "Educational Justice, Epistemic Justice, and Levelling Down."

29 Kotzee, “Educational Justice, Epistemic Justice, and Levelling Down,” 348.

30 McClintock, "Formative Justice"; McClintock, Formative Justice; Thompson, "Rethinking Discussions of Justice in Educational Research."

31 Thompson, "Rethinking Discussions of Justice in Educational Research," 12.

32 I thank two anonymous reviewers for raising these objections.

33 I borrow this example from Kotzee, "Educational Justice, Epistemic Justice, and Levelling Down,” 340.

34 Fricker, Epistemic Injustice, Chapter 2 \& Chapter 7; Kristie Dotson, “A Cautionary Tale: On Limiting Epistemic Oppression,” Frontiers 33, no. 1 (2012): $24-47$.

35 Coady, “Two Concepts of Epistemic Injustice."

36 McClintock, Formative Justice; Thompson, "Rethinking Discussions of Justice in Educational Research."

37 Christopher Martin, "Should Deliberative Democratic Inclusion Extend to Children?," Democracy \& Education 26, no. 2 (2018): 8-10.

38 A. C. Nikolaidis, “A Third Conception of Epistemic Injustice,” Studies in Philosophy and Education (2021), advanced online publication, https://doi. org/10.1007/s11217-021-09760-1. This definition extends a definition of formative epistemic injustice that I provide elsewhere. A. C. Nikolaidis, "Willful Ignorance as Formative Epistemic Injustice," Philosophy of Educa- 
tion 76, no. 4 (2021): 88. Martin's definition differs from my own in that, for Martin, the wrong of formative epistemic injustice only refers to the limiting of one's ability to develop requisite skills for democratic deliberation. Martin, "Should Deliberative Democratic Inclusion Extend to Children?," 9. For the differences between the two accounts see Nikolaidis, "A Third Conception of Epistemic Injustice."

39 Ashley Taylor, "The Logic of Deferral: Educational Aims and Intellectual Disability," Studies in Philosopby and Education 37, no. 3 (2018): 265-285.

40 Kotzee, "Educational Justice, Epistemic Justice, and Levelling Down." 41 For an account of the disabling function of propaganda and ideology see Jason Stanley, How Propaganda Works, (Princeton: Princeton University Press, 2015).

42 Shoshana Zuboff, The Age of Surveillance Capitalism: The Fight for a Human Future at the New Frontier of Power (New York: PublicAffairs, 2019), 293-299. 